\title{
Importance of benthic nutrient regeneration during initiation of macroalgal blooms in shallow bays
}

\author{
Kristina Sundbäck ${ }^{1, *}$, Alison Miles ${ }^{1}$, Stefan Hulth ${ }^{2}$, Leif Pihl ${ }^{3}$, Pia Engström², \\ Erik Selander ${ }^{3}$, Anders Svenson ${ }^{3}$
}

\author{
${ }^{1}$ Department of Marine Ecology, Marine Botany, Göteborg University, Box 461, 40530 Göteborg, Sweden \\ ${ }^{2}$ Department of Chemistry, Analytical and Marine Chemistry, Göteborg University, 41296 Göteborg, Sweden \\ ${ }^{3}$ Department of Marine Ecology, Kristineberg Marine Research Station, Göteborg University, 45034 Fiskebäckskil, Sweden
}

\begin{abstract}
Fast growing ephemeral algae are increasingly observed in shallow coastal waters worldwide. This is generally considered a symptom of coastal eutrophication. It has been suggested that the reoccurrence of macroalgal mats, despite ongoing efforts to decrease nutrient loadings, may be explained by the fact that sheltered bays function as self-regenerating systems through benthic regeneration of nutrients. The importance of benthic nutrient regeneration during the initiation of the growth of filamentous green algal mats was investigated in 2 shallow-water bays on the west coast of Sweden. Nutrient regeneration was assessed in situ and in the laboratory, using sediment-water light/dark incubations and pore water distribution patterns. Benthic efflux of inorganic nutrients could supply up to 55 to $100 \%$ of the estimated nitrogen demand and 30 to $70 \%$ of the phosphorus requirements for the initial macroalgal growth from May to June. However, the availability of the pore water nutrient pool was influenced by the amount and functional type of infauna, and by competition from microphytobenthos. Because of the internal nutrient source of the embayments, it is suggested that there may be a significant time lag between a decreased nutrient supply to coastal waters and improved conditions of shallow water embayments.
\end{abstract}

KEY WORDS: Nitrogen · Nutrient flux · Sediment $\cdot$ Green algae $\cdot$ Infauna $\cdot$ Microphytobenthos · Autotrophy $\cdot$ Heterotrophy

Resale or republication not permitted without written consent of the publisher

\section{INTRODUCTION}

The proliferation of fast growing ephemeral algae in shallow coastal waters is a phenomenon increasingly observed worldwide, and is generally considered a symptom of coastal eutrophication (Valiela et al. 1997). Floating mats of such algae may have dramatic effects on the physics, chemistry and biology of shallow-water coastal ecosystems, particularly in nontidal or microtidal sheltered embayments and lagoons (e.g. Pihl et al. 1996, Viaroli et al. 1996). Apart from the acute dystrophy effects, the mats may out-compete benthic perennial primary producers, such as seagrasses (Hartog 1994, Havens et al. 2001), microphytobenthos (Sundbäck et al. 1990, Fong et al. 1993a), and phytoplankton (Fong et al. 1993b, McGlathery et al. 1997).

*Email: kristina.sundback@marbot.gu.se
Moreover, they may cause large changes in the local foodweb ecology (Isaksson \& Pihl 1992, Isaksson et al. 1994) and reduce the abundance and diversity of benthic macrofaunal species (Norkko \& Bonsdorff 1996, Bolam et al. 2000, Rafaelli 2000, Österling \& Pihl 2001). Efforts have been made to counteract these problems, for example by reducing nutrient runoff from land (e.g. Fleischer et al. 1987) and removing fixed nutrients through direct harvesting of algal mats (Valiela et al. 1997, Jöborn et al. 1998).

To date, the majority of studies on ecological consequences of floating macroalgal mats have been investigating the impact of already established mats (e.g. Krause-Jensen et al. 1999, Trimmer et al. 2000, Astill \& Lavery 2001 and references therein). Studies on nutrient turnover in bays supporting macroalgal mats have 
also shown that the sediment constitutes an important source of regenerated nutrients for maintaining the growth of already established mats (e.g. ThyboChristesen 1993). Only limited work has focused on factors that trigger the actual onset of macroalgal blooms. Generally, the onset is considered to depend on an external input of nutrients to the water column, such as land runoff (e.g. Trimmer et al. 2000). We suggest that regular reoccurrence of algal mats in shallow bays, despite ongoing efforts to decrease nutrient loadings, can be explained by nutrients regenerated in the local sediments rather than nutrients in the water column from external sources.

Filamentous green algal mats (mainly Enteromorpha and Cladophora spp.) frequently develop during late May in shallow microtidal embayments on the west coast of Sweden. They start growing in the inner sheltered parts of the archipelago where the sediment is silty with a high organic carbon content (2 to 8\%) (Pihl et al. 1999). Once established, the algal mats float at the surface and cover about 30 to $50 \%$ of shallow (0 to $1 \mathrm{~m})$ soft-sediment habitats during summer. The characteristics of these mats have been described in detail by Pihl et al. (1996, 1999). It has been suggested that the temporal and spatial distributions of the mats are not related to local point sources of nutrient discharge, but rather to wind and wave exposure and bulk organic content of the sediment (Pihl et al. 1999). Local benthic decomposition of algal and other labile organic material may constitute a major internal source of nutrients able to initiate the growth of new algal mats.

Table 1. Characteristics of the 2 bays during the study period (April to June). Either range or mean is given. Samples for porosity, C, N and chl a content were taken from the top $5 \mathrm{~mm}$, and infaunal biomass from the top $5 \mathrm{~cm}$ of the sediment

\begin{tabular}{|c|c|c|}
\hline & $\begin{array}{l}\text { Rågårdsvik } \\
\text { (RÅ) }\end{array}$ & $\begin{array}{l}\text { Bassholmen } \\
\text { (BA) }\end{array}$ \\
\hline Salinity & $\begin{array}{c}8-27 \\
\text { (mean 22) }\end{array}$ & $\begin{array}{c}19-26 \\
\text { (mean 22) }\end{array}$ \\
\hline Water temperature $\left({ }^{\circ} \mathrm{C}\right)$ & 6-18 & 6-18 \\
\hline Water depth (m) & 0.5 & 0.5 \\
\hline Water column $\mathrm{NH}_{4}^{+}(\mu \mathrm{M})$ & 2.2 & 1.8 \\
\hline Water column $\mathrm{NO}_{3}^{-}+\mathrm{NO}_{2}^{-}(\mu \mathrm{M})$ & 3.9 & 0.86 \\
\hline Water column $\mathrm{PO}_{4}{ }^{3-}(\mu \mathrm{M})$ & 0.4 & 0.4 \\
\hline Sediment porosity & 0.81 & 0.65 \\
\hline Sediment C content $(\%)$ & 2.04 & 1.45 \\
\hline Sediment $\mathrm{N}$ content $(\%)$ & 0.23 & 0.16 \\
\hline Sediment molar $\mathrm{C} / \mathrm{N}$ & 10.3 & 10.6 \\
\hline $\begin{array}{l}\text { Sediment chl a content } \\
\qquad\left(\mathrm{mg} \mathrm{m}^{-2}\right)\end{array}$ & $\begin{array}{c}61-137 \\
\text { (mean 95) }\end{array}$ & $\begin{array}{c}72-112 \\
(\text { mean } 87)\end{array}$ \\
\hline 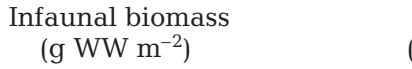 & $\begin{array}{c}18-59 \\
(\text { mean 35) }\end{array}$ & $\begin{array}{c}20-131 \\
(\text { mean } 73)\end{array}$ \\
\hline $\begin{array}{l}\text { Green algal mat } \\
\left.\quad(g \mathrm{DW} \mathrm{m})^{-2}\right)\end{array}$ & 0 & $\begin{array}{c}40 \\
\text { (mean, June) }\end{array}$ \\
\hline
\end{tabular}

Through benthic regeneration of nutrients, sheltered embayments may therefore function as self-regenerating systems that favour the growth of opportunistic macroalgae. A similar mechanism has been suggested to explain the existence of algal mats in other areas, such as the Peel Harvey estuary in Australia (e.g. Hodgkin \& Birch 1986). The role of the benthic system as a local nutrient supply for macroalgal growth was also recently emphasized by a model aimed at predicting the occurrence of algal mats on the Swedish west coast (Eilola \& Stigebrandt 2001).

The aim of this study was to focus specifically on the role of benthic nutrient regeneration for the initiation of the growth of filamentous green algal mats in shallow embayments. Thus, effects and feed-back mechanisms related to the macroalgal mats were outside the scope of our study. The approach was to measure the distribution patterns of pore water nutrients and light and dark sediment-water fluxes (in situ and in the laboratory) during the onset of macroalgal growth and the period just prior (April to June) in 2 shallow bays where ephemeral algal mats are commonly found. In order to estimate macroalgal nutrient demand, growth of green algal mats was monitored during the study period. The possible influence by other functional components on sediment-water fluxes were considered by assessing the biomass and composition of macroscopic infauna and primary production of microphytobenthos.

\section{MATERIALS AND METHODS}

Sites and sampling. The study was conducted between April and June 2000 in 2 shallow, brackishwater bays on the west coast of Sweden: Rågårdsvik $\left(\mathrm{R}_{i} 58^{\circ} 12^{\prime} \mathrm{N}, 11^{\circ} 27^{\prime} \mathrm{E}\right)$ and Bassholmen (BA; $\left.58^{\circ} 15^{\prime} \mathrm{N}, 11^{\circ} 30^{\prime} \mathrm{E}\right)$. These 2 bays were chosen, on the basis of a previous study (Pihl et al. 1999), as being representative of bays that regularly support extensive green algal mats. General characteristics for the sites are given in Table 1. The sampling design was hierarchical with 3 stations (20 m apart) in each bay. At each station, 2 (laboratory incubations) or 3 (field incubations) replicate cores were sampled for benthic flux measurements, and 1 or 2 cores were used for pore water distributions. Three field (April, May and midJune) and 4 laboratory (April, May, mid-June and late June) sediment-water incubations were performed. The 2 June incubations will be referred to as June 1 and June 2. In addition to light and dark fluxes of oxygen and inorganic nutrients ( $\mathrm{N}$ and $\mathrm{P}$ ), and pore water distributions of $\mathrm{N}$ and $\mathrm{P}$, we also sampled for sediment chlorophyll a ( $\mathrm{chl} \mathrm{a)} \mathrm{(a} \mathrm{rough} \mathrm{measure} \mathrm{of} \mathrm{microphyto-}$ benthic biomass), total sediment $\mathrm{C}$ and $\mathrm{N}$ content, and 
biomass and composition of infauna. Biomass and $\mathrm{N}$ content of green algal mats were assessed in each bay during the study period. In situ nutrient concentrations in the overlying water were monitored once a week from April to June. Bottom water temperature increased from 6 to $16^{\circ} \mathrm{C}$ during this period.

Sediment properties. On completion of the nutrient flux measurements (see below), samples for chl a were taken from the top $5 \mathrm{~mm}$ of the surface sediment with a $20 \mathrm{ml}$ syringe and immediately frozen $\left(-80^{\circ} \mathrm{C}\right)$. Pigment concentrations were measured spectrophotometrically (Lorenzen 1967) after extraction with 90\% acetone. Porosity for the top $5 \mathrm{~mm}$ sediment layer was estimated gravimetrically by drying sediment to constant weight at 60 to $70^{\circ} \mathrm{C}$. Solid phase total C and N were determined on dried samples (top $5 \mathrm{~mm}$ ) using a Carlo Erba CHN elemental analyser. Before analysis, samples for organic $\mathrm{C}$ content were treated with $\mathrm{HCl}$ to remove metal carbonates.

Macroscopic infauna. Upon termination of the field incubations, benthic infauna was removed from the cores by sieving the upper $5 \mathrm{~cm}$ of the sediment through a $1 \mathrm{~mm}$ mesh. The fauna were preserved in $70 \%$ ethanol and later identified to the lowest taxonomic level possible under a dissection microscope. Density and biomass (wet weight, shells of molluscs excluded) were estimated for each species/taxon of the infauna for each core. The fauna was classified into functional feeding groups according to Fauchald (1979).

Pore water distributions and calculated diffusive fluxes. Sediment for pore water distribution patterns was sampled using $24 \mathrm{~cm}$ long Plexiglas cores (i.d. $8 \mathrm{~cm}$ ). Subsequent to sampling, the overlying water was siphoned off and the sediment was vertically sectioned at intervals of $2.5 \mathrm{~mm}$ from the interface to a sediment depth of $5 \mathrm{~cm}$. The pore water obtained after centrifugation was filtered $(0.45 \mu \mathrm{m})$ and transferred to polypropylene vials. Samples were stored frozen until analysis within 10 to $14 \mathrm{~d}$.

Diffusive solute fluxes, $J_{\text {diff, }}$ in combination with measured fluxes, are frequently used to estimate transport mechanisms across the sediment-water interface. Fluxes within the sediment and between sediment and overlying water were estimated using Fick's first law of diffusion adapted to sediment conditions (Berner 1980):

$$
J_{\text {diff }}=-\varphi \times D_{\mathrm{s}} \times(\partial C / \partial \mathrm{z})
$$

where $\varphi$ is the porosity in the top layer of the sediment. Flux estimates were obtained by linear concentration gradients $(\partial C / \partial \mathrm{z})$ in the surface sediment layer (assuming no diffusive boundary layer in the overlying water). The whole-sediment diffusion coefficients for the different solutes were calculated from the free solution value, $D_{0}$, corrected for temperature and salinity (viscosity), using the Archie-type relation: $D_{\mathrm{s}} \sim \varphi^{2} D_{\mathrm{o}}$ (Li \& Gregory 1974, Ullman \& Aller 1982, Boudreau 1996).

Measured benthic oxygen and nutrient fluxes. Field and laboratory sediment incubations for nutrient $\left(\mathrm{NH}_{4}{ }^{+}, \mathrm{NO}_{3}{ }^{-}+\mathrm{NO}_{2}{ }^{-}, \mathrm{PO}_{4}{ }^{3-}\right)$ and oxygen fluxes were carried out using $24 \mathrm{~cm}$ long Plexiglas cores (i.d. $8 \mathrm{~cm}$, about $12 \mathrm{~cm}$ of overlying water) with magnetic stirring (60 rpm; for details see Dalsgaard et al. 2000, Sundbäck et al. 2000). In the laboratory, the sediment cores (2 replicates) and 1 blank core (only site water) for each station were incubated at in situ temperature in specially designed tanks containing circulating site water. Incident irradiance (individual $25 \mathrm{~W}$ halogen bulbs over each core) was adjusted to the daily mean for that month (Dalsgaard et al. 2000). For flux measurements in the field, incubation cores were pressed into the sediment ( 3 replicates and 1 blank per station) and the overlying water exchanged several times with ambient bottom water to reduce eventual artefacts associated with core insertion. Stirring was by batterypowered, horseshoe magnets in watertight housings. Before starting the incubations, the water in each core was again replaced by surrounding bottom water. Field incubations were performed 1 or 2 times during the daylight period, and once during night conditions. Incubation time was set so that changes in oxygen concentration within the cores did not exceed $20 \%$. Incubation times (the same for laboratory and field measurements, except in April, when in situ incubations were longer) varied between 1.5 and $5 \mathrm{~h}$, depending on temperature. Fluxes of nutrients and oxygen in light and dark were measured in the same cores. Oxygen flux in the light was used as a measure of net primary production (NP). Gross primary production was calculated as the sum of NP and oxygen consumption in the dark (community respiration, CR). Field oxygen production, estimated from the in situ benthic flux incubations, was recalculated to daily values using the ratio between total daily irradiance and the irradiance during the incubation. Incident light was recorded continuously by a DELTA-T light sensor at the Kristineberg Marine Research Station, a few $\mathrm{km}$ from the sampling sites. Laboratory and field nutrient fluxes, and laboratory oxygen fluxes were recalculated to daily values using length of light and dark period obtained from the DELTA-T light sensor. Nutrient samples were immediately frozen $\left(-80^{\circ} \mathrm{C}\right)$ and stored until analysis, which followed standard colorimetric methods using autoanalyser (TRAACS, Braun-Lubbe).

Green algal growth. The growth of filamentous algae was estimated from 5 replicate biomass samples taken randomly with a cylinder (bottom area $350 \mathrm{~cm}^{2}$ ) on 3 occasions (April, mid June and late June) in the study area of each bay. Algae were identified to gen- 
era and their dry weight was determined. Macroalgal growth was calculated from the initial increase of algal biomass between the April and midJune sampling. As neither turnover nor loss rates were measured, the growth represents a conservative estimate of biomass increase and nutrient accumulation in algal biomass. Therefore, previously published data on green algal growth from the same region on the west coast of Sweden were also applied (Pihl et al. 1996) (Table 2).

Data analyses. Spatial variation was tested using a 3-way nested ANOVA, with time, bay and station (nested within bays) as factors. Differences between light/dark and field/laboratory flux rates were tested using a 2-way ANOVA, with time and treatment as factors. Homogeneity of variances was evaluated using Cochran's test. When variances were found to be heterogeneous, data were transformed according to Underwood (1997). Differences were accepted as significant at $\mathrm{p}<0.05$. Pairways testing of means was done with Student-Newman-Keuls multiple comparison test (SNK). The Pearson Correlation was used to estimate correlations between variables.

\section{RESULTS}

\section{Site characteristics}

Characteristics of the sampling sites are summarized in Table 1. The sediment type of both bays was silty sand, with total sediment carbon content of 2.0 and $1.45 \%$ and nitrogen content of 0.23 and $0.16 \%$ at $\mathrm{R} \AA$ and $\mathrm{BA}$, respectively (Table 1 ). Chl a content of the top $5 \mathrm{~mm}$ sediment varied only slightly with time and space (Fig. 1a), and did not vary significantly between the 3 stations sampled within a bay (3-way nested ANOVA). Epifluorescence microscopy revealed a well developed benthic diatom community at all stations (Sundbäck \& Miles 2002).

At BA, green algal mats (dominated by Enteromorpha spp.) started to appear in May, reaching a mean biomass of $40 \mathrm{~g}$ dry weight (DW) $\mathrm{m}^{-2}$ in mid-June. Although green algal mats commonly occur at RA, no mats appeared during the study period.

The mean biomass of macroscopic infauna in the field-incubated cores varied between 18 and $131 \mathrm{~g}$ wet
Rågårdsvik
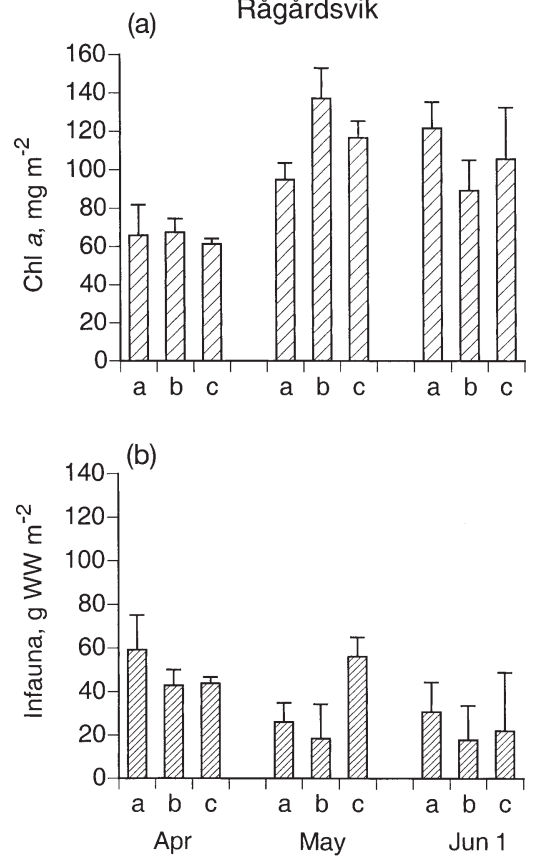

Bassholmen
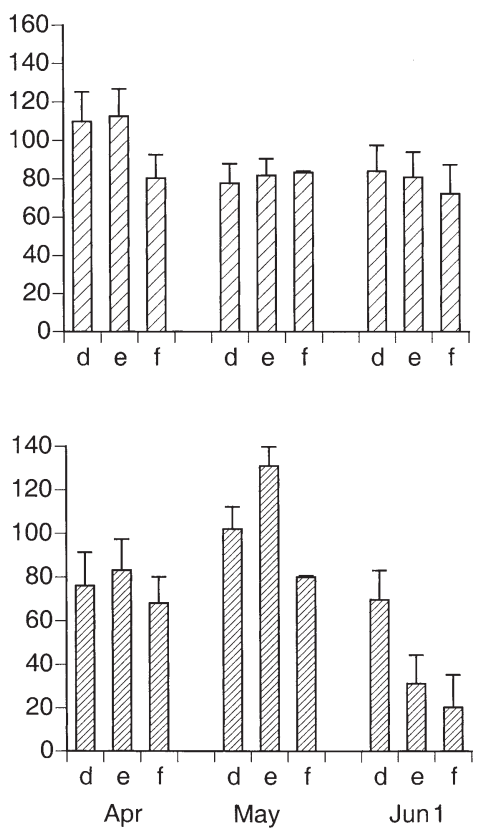

Fig. 1. Chl a content of the top $5 \mathrm{~mm}$ sediment (a) and biomass (wet weight) of infauna (b) in field-incubated cores at Rågårdsvik (Stns a to c) and Bassholmen (Stns d to f) sampled April, May, and mid-June (June 1). Shown are mean values $+\mathrm{SE}(\mathrm{n}=3)$ for each station

weight $(\mathrm{WW}) \mathrm{m}^{-2}$, with significantly higher values at BA (ANOVA; $\mathrm{p}=0.006$ ) (Fig. 1b). Altogether, 30 taxa were identified, with polychaetes (13 species), crustaceans ( 7 species), molluscs (4 species), chironomids and oligochaetes dominating the infauna. The predominant feeding mode among identified species was surface and sub-surface deposit feeding (12 species), and 3 species were classified as filter feeders and 3 as predators. At R̊, Chironomidae and Hydrobia sp. dominated in terms of both density and biomass, while the crustacean Corophium volutator alone constituted a major part (68 to $73 \%$ ) of the benthic biomass at BA.

\section{Nutrient concentrations}

Water column concentrations of dissolved inorganic nitrogen (DIN) were generally below $5 \mu \mathrm{M}$ (Table 1), with the exception of a nitrate peak of $21 \mu \mathrm{M}$ at $\mathrm{R} \AA$ in April. Although there were small differences in concentrations between sites, $\mathrm{NH}_{4}{ }^{+}$and $\mathrm{NO}_{3}{ }^{-}$were significantly higher $(\mathrm{p}<0.05)$ at $\mathrm{R} \AA$ (also when excluding the highest peak of $\mathrm{NO}_{3}{ }^{-}$). Phosphate concentrations were low $(0.1$ to $0.6 \mu \mathrm{M})$ and often close to, or below, detection limit $(0.05 \mu \mathrm{M})$.

Pore water nutrient concentrations in the top $5 \mathrm{~cm}$ of the sediment varied in magnitude and depth within 


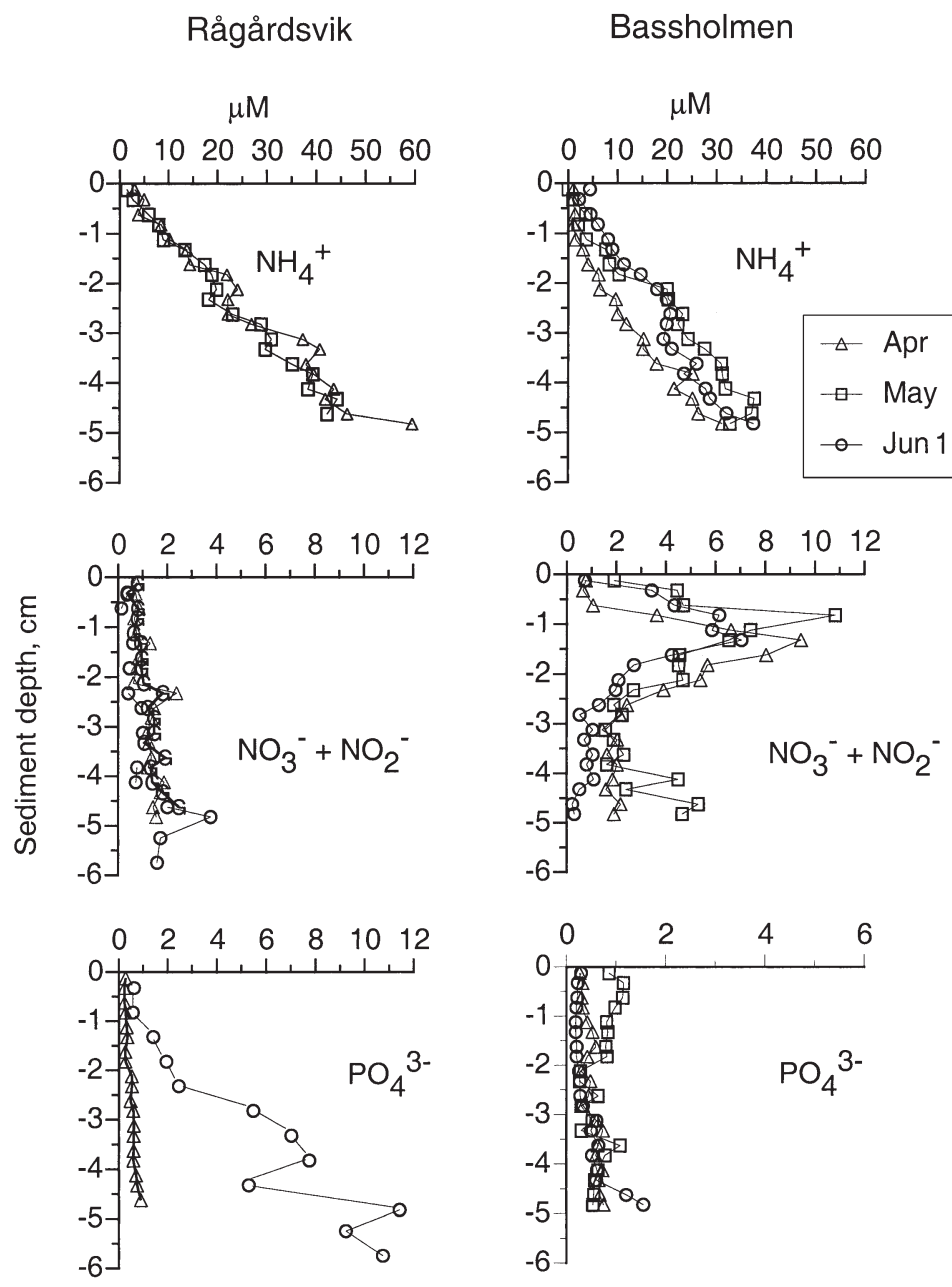

Fig. 2. Pore water nutrient distributions at Rågårdsvik and Bassholmen in April, May and mid-June (June 1). Each profile represents 1 core, except in April at Bassholmen (mean of 2 cores)

and between the 2 bays (Fig. 2). At $\mathrm{R} \AA, \mathrm{NH}_{4}{ }^{+}$concentrations increased linearly with depth, although the $\mathrm{NH}_{4}{ }^{+}$concentration was the same as in the overlying water in a surface layer just below the sediment-water interface (top $3 \mathrm{~mm}$ ) (Fig. 2). The magnitude and patterns of $\mathrm{NH}_{4}{ }^{+}$and $\mathrm{NO}_{3}{ }^{-}$concentrations at $\mathrm{R} \AA$ were almost identical in April, May $\left(\mathrm{NO}_{3}\right)$ and June. $\mathrm{NH}_{4}{ }^{+}$ and $\mathrm{NO}_{3}{ }^{-}$profiles showed no evidence of $\mathrm{NH}_{4}{ }^{+}$oxidation. This in conjunction with increasing phosphate concentrations with depth (June), indicated limited oxygen availability below the photosynthetic layer in RÅ surface sediments (Fig. 2).

At BA, constant $\mathrm{NH}_{4}{ }^{+}$concentrations just below the sediment-water interface were followed by an $\mathrm{NH}_{4}{ }^{+}$ mobilization to the pore water. In the oxidized surface layer (0 to $2 \mathrm{~cm}$ ), there was a progressive oxidation of $\mathrm{NO}_{2}{ }^{-}$and $\mathrm{NO}_{3}{ }^{-}$. A build up of DIN, largely as $\mathrm{NH}_{4}{ }^{+}$, normally occurred with depth in the sediment. In the anoxic or suboxic layer there was a net $\mathrm{NO}_{3}{ }^{-}$ removal, and pore water $\mathrm{NO}_{3}{ }^{-}$reached concentrations of ca. $2 \mu \mathrm{M}$. These patterns are typical of the classically recognized succession of DIN speciation during $\mathrm{N}$ mineralisation (Fig. 2). Nitrate was not completely depleted at $5 \mathrm{~cm}$ (the deepest section analyzed), indicating transfer of oxygenated bottom water to at least this depth in the sediment, although artefactual contribution from ammonium oxidation during core sectioning cannot be excluded. Oxidising conditions and scavenging of dissolved phosphorus to ironoxide surfaces were supported by observations of pore water phosphate below $2 \mu \mathrm{M}$ at all sampling occasions.

\section{Measured oxygen and nutrient fluxes}

As oxygen and nutrient flux rates did not vary significantly between stations within a bay (nested 3-way ANOVA), only between-bay comparisons are presented.

There was no general overall difference between daily oxygen fluxes measured in the laboratory (L) and in the field (F), although a significant time $\times$ L/F interaction (2-way ANOVA) indicated that fluxes were occasionally different (Fig. 3). Daily oxygen fluxes in light varied between a net consumption of $40 \mathrm{mmol} \mathrm{m} \mathrm{m}^{-2} \mathrm{~d}^{-1}$ (BA) and a net production of $58 \mathrm{mmol} \mathrm{m} \mathrm{m}^{-2} \mathrm{~d}^{-1}$ (RA). There was a general difference in the benthic trophic state between the 2 bays. During daytime, $\mathrm{R} \AA$ was an autotrophic system (net $\mathrm{O}_{2}$ production), while BA was mainly heterotrophic (net $\mathrm{O}_{2}$ consumption) (Fig. 3). Calculated net $\mathrm{O}_{2}$ fluxes over a $24 \mathrm{~h}$ period also suggested that $\mathrm{R} \AA$ sediments mainly constituted an oxygen producing system (6 to $46 \mathrm{mmol} \mathrm{O}_{2}$ produced $\mathrm{m}^{-2} 24 \mathrm{~h}^{-1}$ ), except in April, while BA sediments constituted an oxygen consuming system (12 to $55 \mathrm{mmol} \mathrm{O}_{2}$ consumed $\mathrm{m}^{-2}$ $24 \mathrm{~h}^{-1}$ ), except in late June. Community respiration (CR) was within the same range in both bays (Fig. 3).

Statistically significant differences between measured hourly light and dark nutrient fluxes were found, with uptake or lower effluxes during the light period. However, nutrient fluxes are presented here as averaged daily fluxes.

Measured mean fluxes of DIN $\left(\mathrm{NH}_{4}{ }^{+}+\mathrm{NO}_{3}{ }^{-}+\mathrm{NO}_{2}^{-}\right)$ varied between an uptake of $1430 \mu \mathrm{mol} \mathrm{m} \mathrm{m}^{-2} \mathrm{~d}^{-1}$ and an efflux of $2900 \mu \mathrm{mol} \mathrm{m}{ }^{-2} \mathrm{~d}^{-1}$ (Fig. 4). No significant differences between laboratory and field fluxes of DIN were found at BA. However, at R ence was found in May, when there was an uptake in 


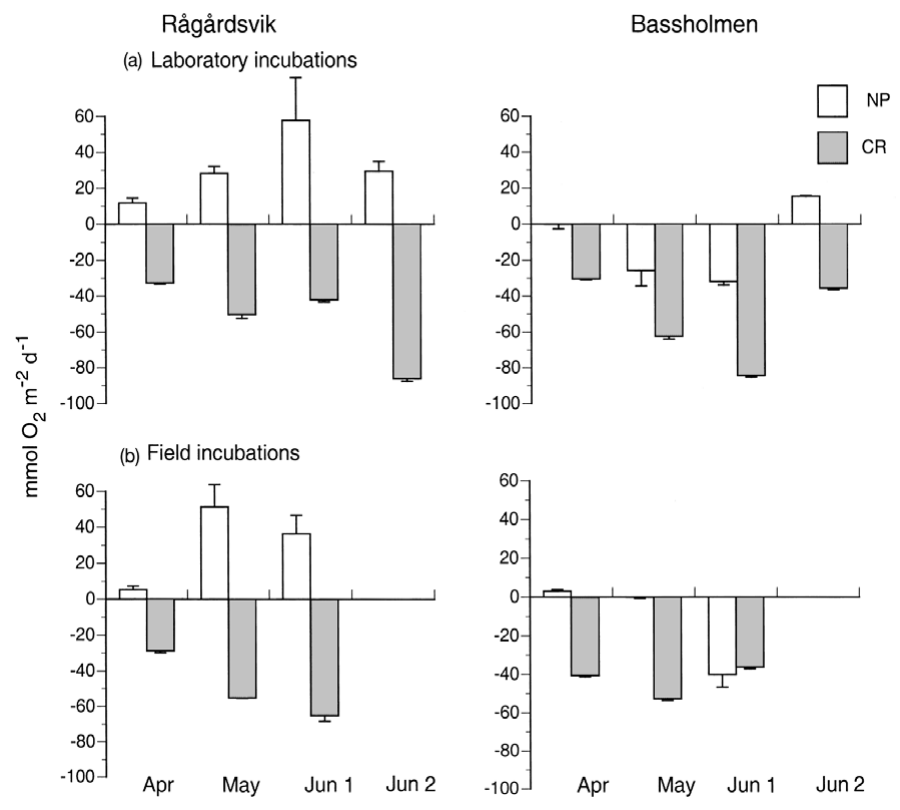

Fig. 3. Daily net primary productivity (NP) and community respiration (CR) at Rågårdsvik and Bassholmen expressed as daily oxygen fluxes. Bars show mean $+\mathrm{SE}(\mathrm{n}=6$ for laboratory, $\mathrm{n}=9$ for field incubations). June $1=$ mid-June, June $2=$ late June. Fluxes for late June were measured only in the laboratory

the laboratory, but an efflux (mainly of $\mathrm{NH}_{4}{ }^{+}$) in the field cores. Two trends appeared for the DIN fluxes: (1) Flux rates increased significantly between the sampling in April and May, coinciding with a water temperature increase of $10^{\circ} \mathrm{C}$. (2) Measured effluxes of DIN were generally larger for BA sediments compared

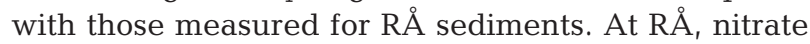
was mainly taken up by the sediment, flux rates varying from 50 to $-200 \mu \mathrm{mol} \mathrm{m} \mathrm{m}^{-2} \mathrm{~d}^{-1}$. At BA, there was an efflux of nitrate (120 to $1480 \mu \mathrm{mol} \mathrm{m}{ }^{-2}$ day $^{-1}$ ) from May onwards (not shown). The nitrate efflux was roughly of the same magnitude as the $\mathrm{NH}_{4}{ }^{+}$efflux (710 to $2700 \mu \mathrm{mol} \mathrm{m}{ }^{-2} \mathrm{~d}^{-1}$ ).

Measured sediment fluxes of phosphate were low (from -15 to $+60 \mu \mathrm{mol} \mathrm{m} \mathrm{m}^{-2} \mathrm{~d}^{-1}$ and often close to the detection limit (Fig. 5).

\section{Calculated diffusive nutrient fluxes}

Generally, diffusive fluxes of DIN and phosphate agreed well with measured fluxes at BA, whereas diffusive fluxes appeared higher than measured fluxes at RÅ (Figs. 4 \& 5). Pore water ammonium distributions were similar, but nitrate distributions were different between the 2 bays (Fig. 2). Nearly constant $\mathrm{NO}_{3}{ }^{-}$concentrations with depth at $\mathrm{R} \AA$ were reflected in low (90 to $140 \mu \mathrm{mol} \mathrm{m} \mathrm{m}^{-2} \mathrm{~d}^{-1}$ ) diffusive fluxes of nitrate across the sediment-water interface (not shown). These low diffusive nitrate fluxes were confirmed by low measured flux rates at the site $(+50$ to -200 to $\mu$ mol $\mathrm{m}^{-2} \mathrm{~d}^{-1}$ ). Pronounced nitrification in the oxic surface layer, followed by distinct removal of nitrate in the anoxic-suboxic zone of the sediment (Fig. 2), made sediments at BA an overall source of nitrate. Calculated nitrate fluxes to the sediment-water interface were about $250 \mu \mathrm{mol} \mathrm{m} \mathrm{m}^{-2} \mathrm{~d}^{-1}$ in April and May, and slightly lower in June $\left(90 \mu \mathrm{mol} \mathrm{m} \mathrm{m}^{-2} \mathrm{~d}^{-1}\right)$. In April, measured fluxes were slightly negative, i.e. nitrate was taken up by the sediment. Detailed studies of nitrate distributions at BA during April indicated a transport of nitrate from the zone of maximum nitrification to a surface layer in the top ca. $7.5 \mathrm{~mm}$ of the sediment. The
Rågårdsvik

(a) Laboratory incubations

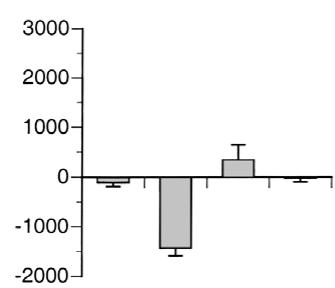

(b) Field incubations

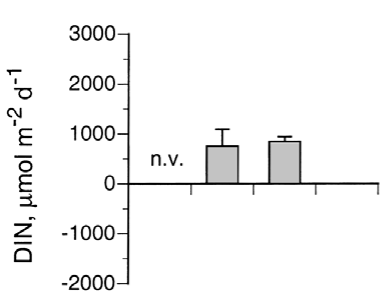

(c) Diffusive fluxes 29000

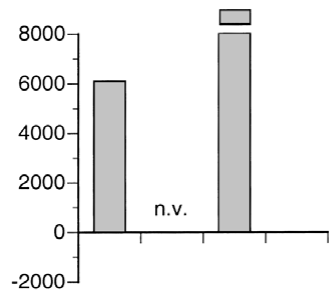

Apr May Jun 1 Jun 2

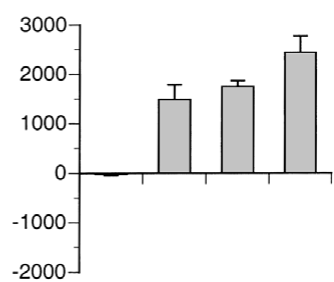

$-2000$

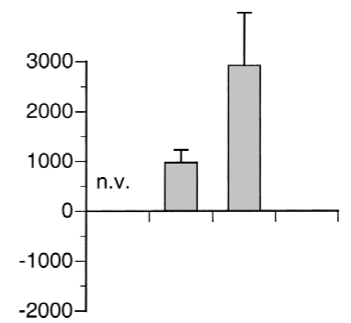

$-2000-$

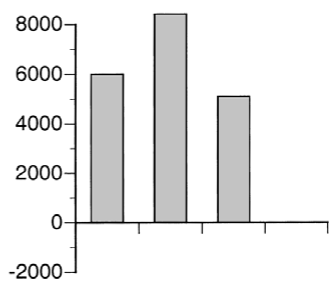

Apr May Jun 1 Jun 2
Fig. 4. Daily fluxes of dissolved inorganic nitrogen (DIN = $\mathrm{NO}_{3}{ }^{-}+\mathrm{NO}_{2}^{-}+\mathrm{NH}_{4}{ }^{+}$) measured in laboratory (a) and field incubations (b), and diffusive fluxes calculated from concentration gradients in the top sediment layer using Fick's law of diffusion adapted to sediments (Berner 1980) (c). June $1=$ mid-June, June 2 = late June. Fluxes for late June were measured only in the laboratory. Bars show mean $+\mathrm{SE}(\mathrm{n}=6$ for laboratory, $\mathrm{n}=9$ for field, and $\mathrm{n}=1$ for diffusive fluxes); $\mathrm{n} . \mathrm{v}$. = no value 
Rågårdsvik

Bassholmen

(a) Laboratory incubations

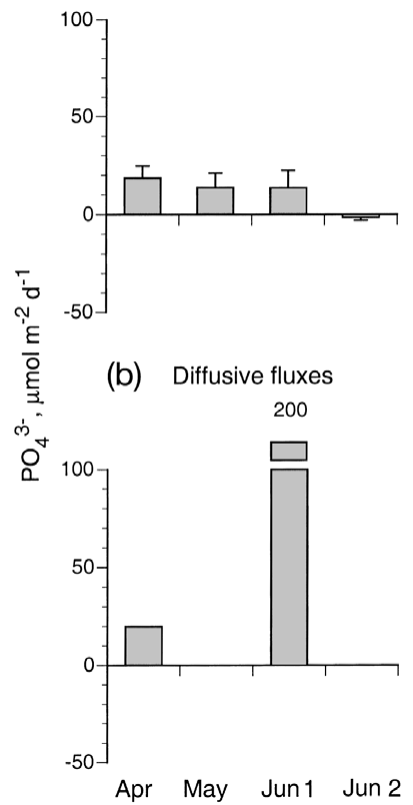

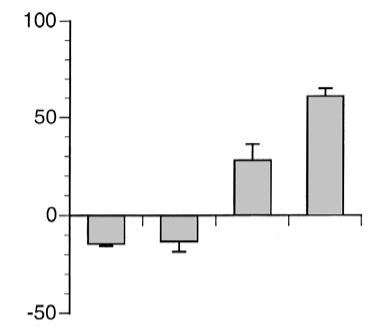

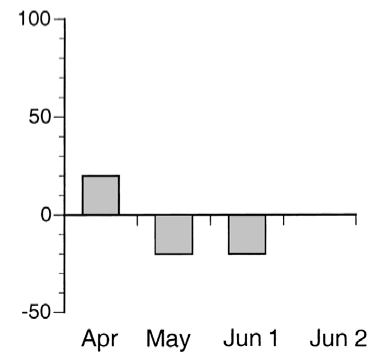

Fig. 5. Daily fluxes of dissolved inorganic phosphorus $\left(\mathrm{PO}_{4}{ }^{3-}\right)$ measured in laboratory incubations (a), and diffusive fluxes calculated from pore water nutrient profiles (b). June $1=$ midJune, June 2 = late June. Fluxes for late June (June 2) were only measured in the laboratory. Bars show mean $+\mathrm{SE}(\mathrm{n}=6$ for laboratory, and $\mathrm{n}=1$ for diffusion fluxes)

observed $\mathrm{NO}_{3}{ }^{-}$consumption was most likely attributed to subsurface benthic denitrification in anoxic microenvironments or incorporation of nitrate into biomass (bacteria and photosynthetic microalgae; Sundbäck \& Miles 2002). Such subsurface sinks of $\mathrm{NO}_{3}{ }^{-}$(and $\mathrm{NH}_{4}{ }^{+}$) may bias estimated fluxes of nitrate across the sediment-water interface and at least partly explain measured DIN fluxes into the sediment (Figs. 2 \& 4).

Ammonium concentration gradients at BA (Fig. 2) indicated a significant transport of $\mathrm{NH}_{4}{ }^{+}$from depth to the layer just below the interface, supporting observations of possible subsurface $\mathrm{N}$ sinks at the site. Calculated diffusive fluxes to depths of 5 to $10 \mathrm{~mm}$ suggested this transport to be 2 to 13 times higher than calculated $\mathrm{NH}_{4}{ }^{+}$fluxes across the sediment-water interface (data not shown). A constant increase of $\mathrm{NH}_{4}{ }^{+}$concentrations to the deepest sediment layer detected $(5 \mathrm{~cm})$ gave no clear indications of a similar $\mathrm{NH}_{4}{ }^{+}$transport at RA (Fig. 2).

Estimated fluxes of phosphate were small and close to the detection limit (-20 to $20 \mu \mathrm{mol} \mathrm{m} \mathrm{m}^{-2} \mathrm{~d}^{-1}$ ) (Fig. 5). However, a significant release of phosphate was calculated for $\mathrm{R} \AA$ in June. At present we have no obvious explanation for this observation, as $\mathrm{NH}_{4}^{+}$and $\mathrm{NO}_{3}{ }^{-}$ concentrations were similar in April and June.

\section{Macroalgal growth rate and nutrient demand}

The importance of sediment nutrient fluxes for meeting the demand of the early growth of green algae was calculated from the net mean biomass increase and $\mathrm{N}$ content of the green algal mats that developed at BA. To enable a comparison of the role of sediment efflux between the 2 bays, the growth rate of macroalgae at BA was applied, hypothetically, also for RA (Table 2), although no macroalgal mats developed at RA during the study period. A mean daily (net) green algal growth rate of $1.3 \mathrm{~g} \mathrm{DW} \mathrm{m}^{-2} \mathrm{~d}^{-1}$ was measured for the period mid-May to mid-June. The mean total organic nitrogen (TON) content was $2.5 \%$, corresponding to a mean $\mathrm{N}$ demand of $2.32 \mathrm{mmol} \mathrm{m} \mathrm{m}^{-2} \mathrm{~d}^{-1}$. Since algal $\mathrm{P}$ content was not measured in our study, we used the mean P content $(0.2 \%$ of dry weight) of similar mats collected in May from 4 bays in the Tjärnö area, ca. $70 \mathrm{~km}$ north of our locations on the Swedish west coast (Melin 2001). This gave an estimated $P$ demand of $84 \mu \mathrm{mol} \mathrm{P} \mathrm{m} \mathrm{P}^{-1}$, resulting in a N:P ratio $27: 1$. The mean N:P ratio in the Tjärnö area during May was 24 (Melin 2001).

As our data for macroalgal growth was based on only a few measuring occasions, we also applied previous growth data on green algal growth from the same region on the Swedish west coast (Pihl et al. 1996). In that study, growth rates of Enteromorpha flexuosa and E. linza were assessed in cage experiments, resulting in growth rates between 1 and $3 \mathrm{~g} \mathrm{DW} \mathrm{m}^{-2} \mathrm{~d}^{-1}$ (Fig. 6 in Pihl et al. 1996). These rates resulted in a maximum

Table 2. Importance of sediment as a nutrient source for the initial growth of green-algal mats during the period April to June, based on laboratory (Lab) and field (in situ) incubations. Values outside brackets are based on a macroalgal demand calculated in the present study $(2.32 \mathrm{mmol} \mathrm{N}$ and $0.084 \mathrm{mmol}$ $\mathrm{P} \mathrm{m}^{-2} \mathrm{~d}^{-1}$ ); the values within brackets are calculated from the highest growth rate measured for Enteromorpha spp. in field cage experiments in the same region (Pihl et al. 1996), resulting in uptake rates of $5.36 \mathrm{mmol} \mathrm{N}$ and $0.20 \mathrm{mmol} \mathrm{P} \mathrm{m} \mathrm{m}^{-2} \mathrm{~d}^{-1}$. For phosphorus, only laboratory fluxes are shown. -: no value or not measured. June 1 = mid-June, June 2 = late June

\begin{tabular}{|c|c|c|c|c|}
\hline Bay & April & May & June 1 & June 2 \\
\hline \multicolumn{5}{|c|}{$\begin{array}{l}\text { Sediment flux as \% of macroalgal N demand } \\
\text { Rågårdsvik }\end{array}$} \\
\hline Lab & $0(0)$ & $0(0)$ & $15(6)$ & $0(0)$ \\
\hline In situ & - & 32 (14) & 36 (16) & - \\
\hline \multicolumn{5}{|l|}{ Bassholmen } \\
\hline Lab & $0(0)$ & $64(28)$ & $75(33)$ & $105(45)$ \\
\hline In situ & - & $42(18)$ & $125(54)$ & - \\
\hline \multicolumn{5}{|c|}{ Sediment flux as \% of macroalgal P demand } \\
\hline Rågårdsvik Lab & $22(9)$ & $16(7)$ & $16(7)$ & $0(0)$ \\
\hline Bassholmen Lab & $0(0)$ & $0(0)$ & 33 (13) & $73(31)$ \\
\hline
\end{tabular}


calculated macroalgal demand of $5.36 \mathrm{mmol} \mathrm{N}$ and $0.2 \mathrm{mmol} \mathrm{P} \mathrm{m}^{-2} \mathrm{~d}^{-1}$ (cf. Table 2).

\section{DISCUSSION}

\section{Benthic nutrient regeneration and macroalgal demand}

Our results suggested that, during spring, nutrients released from the sediment could constitute a substantial share of the nutrient demand for early green algal growth (Table 2). Comparisons of green algal $\mathrm{N}$ demand based on our measurements of net biomass increase with measured effluxes of DIN and DIP indicated that benthic nutrient regeneration contributed 15 to $125 \%$ of the $\mathrm{N}$ demand and 16 to $73 \%$ of the P demand, from May onwards (Table 2), i.e. during the period that coincides with the onset of macroalgal growth. Our 2 study bays contrasted as to whether the sediments could actually meet the entire inorganic nutrient demand of green algae. At BA, the DIN flux could support up to $100 \%$ of the calculated demand in June, and the flux of DIP supported up to ca. $70 \%$ of the P demand. At R $\AA$, the sediment contribution of DIN and DIP was at most ca. 35 and $20 \%$, respectively. No macroalgal mats appeared at RÅ during the study period.

It could be argued that our calculated growth rate (and hence the $\mathrm{N}$-demand) of the macroalgal mat underestimates the actual nutrient uptake of the green algae (as loss rates are not known), and therefore overestimates the importance of sediment nutrients as a source for the initial growth rate. However, growth rate $\left(1.3 \mathrm{~g} \mathrm{DW} \mathrm{m}^{-2} \mathrm{~d}^{-1}\right)$ of the Enteromorpha mat at BA is well within the range of rates assessed for Enteromorpha in cage experiments in the same region (1 to $3 \mathrm{~g} \mathrm{DW} \mathrm{m}^{-2} \mathrm{~d}^{-1}$; Pihl et al. 1996). Applying the highest measured growth rate $\left(3 \mathrm{~g} \mathrm{DW} \mathrm{m}^{-2} \mathrm{~d}^{-1}\right)$ implies that the sediment contribution of DIN and DIP could be lower, but still provide up to $54 \%$ of the macroalgal $\mathrm{N}$-demand and $31 \%$ of the P demand in at BA (Table 2, values in brackets). This suggests that even if regenerated nutrients did not meet the full demand of the green algae, the sediment efflux could still be a critical source for supporting the initial growth of the green algal mats.

Pihl et al. (1999) found that the organic content of the sediment was higher $(>2 \%)$ in bays that supported green algal growth. In our study, the organic C (and N) content of the sediment was actually somewhat lower at BA (1.45 and $0.16 \%$, respectively) when compared with R̊ (2.0 and $0.23 \%$, respectively), suggesting that factors other than sediment organic carbon content per se were essential for regulating nutrient fluxes across the sediment-water interface. Furthermore, bulk POC content of the sediment may not give sufficiently accurate and detailed information on the amount of dissolved $\mathrm{N}$ and $\mathrm{P}$ available for macroalgal growth. Additional explanations for the observed between-bay difference in fluxes include macrofaunal activity and nutrient competition from primary producers at the sediment surface. Our results provide indirect evidence that these 2 components may be important for regulating the onset of green algal blooms during early spring in shallow-water environments, and are therefore discussed below.

\section{Spatial variability}

The main spatial variation in measured benthic solute fluxes was on the level of bays. Considering the lower efflux rates observed at RÅ (Figs. 4 \& 5), an appealing conclusion is that no macroalgal growth occurred at RÅ because of insufficient benthic supply of nutrients. However, actual mechanisms that prevented green algal growth at $\mathrm{R} \AA$ were most likely more complex than a single factor phenomenon. For example, modeling of green algal growth in similar embayments on the Swedish west coast indicated that wind action, hydrodynamic conditions in the bottom water and the dimension and shape of the embayment are important factors that control the onset of algal growth (Eilola \& Stigebrandt 2001).

\section{Effect of benthic fauna}

Infaunal activity typically results in complex patterns of oxic and anoxic microenvironments that strongly influence benthic C and N mineralization (Aller 1982, Glud et al. 1996, Hulth et al. 2002). Bio-turbation and bio-irrigation stimulate nitrification and coupled nitrification/denitrification (Kristensen \& Blackburn 1987, Rysgaard et al 1995, Gilbert et al. 2003). Furthermore, faunal activities may increase solute transport across the sediment-water interface several-fold (Christensen et al. 2000, Emmerson \& Raffaelli 2000, Berg et al. 2001). In our 2 bays, there was a pattern of enhanced DIN fluxes in cores with a high biomass of benthic infauna. The pattern was clearest in May, when there was a significant positive correlation between total infaunal biomass and daily DIN flux (Fig. 6a). In both bays there was a positive linear correlation between daily $\mathrm{NH}_{4}{ }^{+}$flux and faunal biomass, although not significant (Fig. 6b). Burrowing, tube-building, and reworking species were dominant among the infauna, with a total biomass at BA about double that at RA. The amphipod Corophium volutator, an efficient bioturba- 
(a) DIN vs infauna

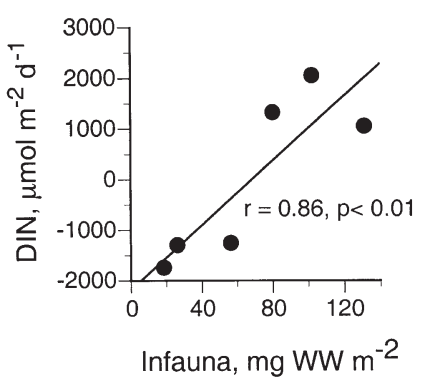

(b) $\mathrm{NH}_{4}$ vs infauna

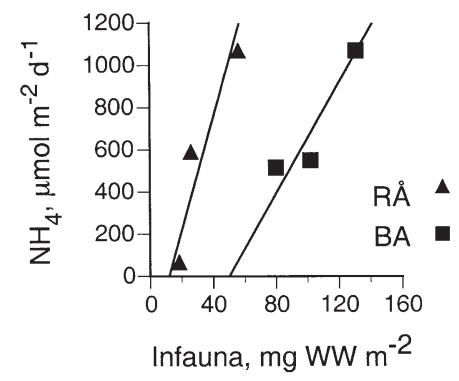

(c) $\mathrm{NO}_{3}$ vs Corophium

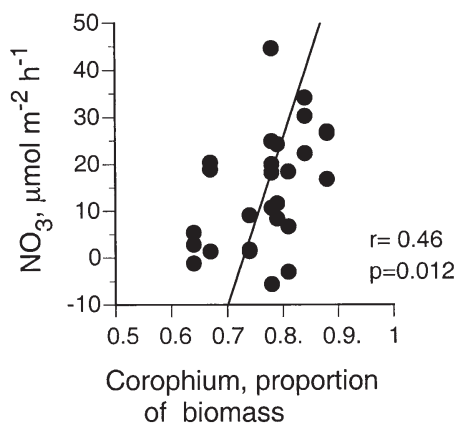

Fig. 6. Correlation between macroscopic infauna and sediment-water nitrogen fluxes in cores incubated in situ in May. Daily DIN $\left(\mathrm{NO}_{3}{ }^{-}+\mathrm{NO}_{2}{ }^{-}+\mathrm{NH}_{4}{ }^{+}\right)$fluxes plotted against total biomass of infauna (a); daily $\mathrm{NH}_{4}{ }^{+}$fluxes plotted against total biomass of infauna (b); hourly $\mathrm{NO}_{3}{ }^{-}$fluxes plotted against proportion of Corophium volutator biomass (c). In (a) and (b), each symbol represents the mean value for 1 station ( $\mathrm{n}=3$ per station), in (c) each symbol represents an individual core

tor (Mazik \& Elliot 2000), made up $70 \%$ of the biomass at BA sediments, enhancing bacterial $\mathrm{N}$ turnover and DIN fluxes across the sediment-water interface (Pelegri et al. 1994). Emmerson et al. (2001) showed in experimental manipulations that there was a positive linear relationship between sediment efflux of $\mathrm{NH}_{4}^{+}$ and the density of $C$. volutator. At BA, where C. volutator dominated among the infauna, the proportion of C. volutator of the total infaunal biomass was significantly ( $p=0.012$ ) and positively correlated with the efflux of nitrate from the sediment (Fig. 6c). A positive linear relationship was also found for ammonium, though not statistically significant. These results indicate the important role of this species for the sedimentwater interface fluxes. Pronounced activity of faunal species that stimulate $\mathrm{N}$ mineralization and promote DIN fluxes across the sediment-water interface could therefore partly explain the higher fluxes of DIN observed at BA. The observation of higher calculated diffusive fluxes than measured fluxes (Fig. 4) are most likely attributed to artefacts associated with a nonsteady state situation or too coarse a vertical resolution in the surface sediment during core sectioning, not reflecting mineralization processes just at the sedimentwater interface.

\section{Competition by microphytobenthos}

Illuminated shallow-water sediments may remove or retain bio-available $\mathrm{N}$ mainly in 3 different ways: denitrification, assimilation by primary producers, and burial of organic N. In addition to green algae, other important primary producers in shallow soft-bottom embayments are seagrasses and microphytobenthos (Havens et al. 2001, McGlathery et al. 2001). A clear seasonality in the dominance of these primary producers is common (e.g. McGlathery et al. 2001), although in our type of cool temperate areas, microphytobenthos (MPB) is present throughout the year, contributing to a net autotrophic community, particularly in sandy sediments (Sundbäck et al. 2000). Thus, MPB was already well developed at the onset of the macroalgal growth, being the only primary-producing benthic component of importance during the first 3 sampling occasions. Small specimens of the rooted seagrass Ruppia sp. were found in some of the cores from RA during the second June incubation, and may have contributed slightly to the primary productivity. Generally, the benthic community at RA appeared autotrophic, while sediments at BA were heterotrophic. This difference was apparently not due to a higher community respiration (Fig. 3), but rather reflected a higher photosynthetic activity of MPB at RA. Although chl a values were similar for both bays, the vertical distribution of the MBP biomass may have been different. At BA the biomass may have been redistributed away from the photic zone (usually $<3 \mathrm{~mm}$ ) of the sediment by a greater bioturbation, thereby decreasing the MPB productivity.

A conservative estimation of the importance of microphytobenthic activity for temporary $\mathrm{N}$ removal can be approximated from net oxygen production (NP), assuming a photosynthetic quotient (production of $\mathrm{O}_{2}$ /consumption of $\mathrm{CO}_{2}$ ) of 1.2 and a $\mathrm{C} / \mathrm{N}$ molar ratio of 9 (Sundbäck et al. 2000). The $\mathrm{N}$ demand of MPB was calculated to be ca. $3.2 \mathrm{mmol} \mathrm{m} \mathrm{m}^{-2} \mathrm{~d}^{-1}$ at $\mathrm{R} \AA$ and ca. $1.2 \mathrm{mmol} \mathrm{m}^{-2} \mathrm{~d}^{-1}$ at BA (Sundbäck \& Miles 2002), corresponding to 140 and $50 \%$ of the green algal demand at $\mathrm{R} \AA$ and $\mathrm{BA}$, respectively. If the literature value $5.36 \mathrm{mmol} \mathrm{N} \mathrm{m}^{-2} \mathrm{~d}^{-1}$ for macroalgal $\mathrm{N}$-uptake was applied (Pihl et al. 1996), the N demand of MPB would 
correspond to roughly $60 \%$ of the macroalgal demand at $\mathrm{R} \AA$, and ca. $22 \%$ at BA. However, it must be kept in mind that also the estimated MPB nutrient demand is a conservative measure, as it is based on net productivity. It is suggested that the activity of MPB in surface sediments at R $\AA$ may have efficiently decreased the rate (and probably also changed the quality and $\mathrm{N}$-speciation) of the potential DIN efflux from the sediment to the macroalgae in the water column (cf. Sundbäck et al. 1996, Thornton et al. 1999 and references therein).

Nitrate reduction through denitrification is an additional process competing for the nitrate available in the pore water (e.g. Rysgaard et al. 1995). At R̊, N removal by denitrification was only a small portion (approximately 20\%) compared to calculated MPBassimilation of $\mathrm{N}$, while at $\mathrm{BA}$, denitrification rates were approximately of the same magnitude as the sediment efflux of DIN (Sundbäck \& Miles 2002). Enhanced microphytobenthic activity is generally considered to depress denitrification through competition during low-N situations and in N-limited ecosystems (Rysgaard et al. 1995, Sundbäck et al. 2000).

\section{Methodological considerations}

Generally, benthic flux rates from field and laboratory sediment-water incubations were consistent, and no significant difference in overall spatial and temporal patterns were found (Figs. $3 \& 4$ ). We do not believe that slightly higher in situ flux rates at RA were attributed to the incubation techniques, but were rather a consequence of natural spatial variations in shallowwater sediments. Since the same type of incubation chambers were used in the field and in the laboratory, the main source for discrepancy was most likely the light level during the incubation. During the laboratory incubations, the applied irradiance was constant (mean daily value). In the field, however, natural light conditions were highly variable. Consequently, shortterm (hourly) flux rates, in situ and in the laboratory, cannot be directly compared. However, when recalculated to daily values, flux rates can be compared, and were found to be similar. Considering the practical difficulties normally associated with in situ incubations, our study suggests that controlled laboratory incubations are as good for benthic solute fluxes in shallow water environments. For the outcome of flux measurements in shallow water sediments, factors in the design of incubation chambers (e.g. size, shape, type of stirring) may be more critical (cf. Asmus et al. 1998) than whether incubations are made in the laboratory or in the field.

\section{CONCLUSIONS}

Notwithstanding the limitations of our study (investigations covered a limited number of sites during 1 spring period), we found support for the hypothesis of embayments as self-regenerating systems. The main conclusions are: (1) Benthic regeneration may constitute a substantial source of inorganic nutrients for the onset of macroalgal blooms in spring. (2) The availability of the pore water nutrient pool is, however, influenced by the amount and functional type of infauna, and by competition from microphytobenthos at the sediment water interface. (3) Because of the internal nutrient source of the embayments, there may be a significant time lag between a decreased nutrient supply to coastal waters and improved conditions in the ecosystems of shallow water embayments.

Acknowledgements. The study was financially supported by the County Administration of Västra Götaland within the frame of the EU-Life Algae project (LIFE96ENV/S/380), the Swedish Natural Science Research Council (NFR), the Foundation for Strategic Environmental Research (MISTRA), the Royal Society of Arts and Sciences in Göteborg, and the Funds of Captain Stenholm and Birgit and Birger Wåhlström. Lars Gamfeldt ran the statistical tests and Malin Hansson provided help during field sampling. We thank 4 anonymous referees for constructive comments.

\section{LITERATURE CITED}

Aller RC (1982) The effects of macrobenthos on chemical properties of marine sediment and overlying water. In: McCall PL, MJS Tevesz (eds) Animal-sediment relations. Plenum, New York, p 53-102

Asmus RM, Jensen MH, Jensen KM, Kristensen E, Asmus H, Wille A (1998) The role of water movement and spatial scaling for measurement of dissolved inorganic nitrogen fluxes in intertidal sediments. Estuar Coast Shelf Sci 46: $221-232$

Astill H, Lavery PS (2001) The dynamics of unattached benthic macroalgal accumulations in the Swan-Canning Estuary. Hydrol Process 15:2387-2399

Berg P, Rysgaard S, Funch P, Sejr MK (2001) Effects of bioturbation on solutes and solids in marine sediments. Aquat Microb Ecol 26:81-94

Berner RA (1980) Early diagenesis: a theoretical approach. Princeton University Press, Princeton, NJ

Bolam SG, Fernandes TF, Read P, Raffaelli D (2000) Effects of macroalgal mats on intertidal sandflats: an experimental study. J Exp Mar Biol Ecol 249:123-137

Boudreau BP (1996) The diffusive tortuosity and porosity of fine-grained sediments. Geochim Cosmochim Acta 60: $3139-3142$

Christensen B, Vedel A, Kristensen E (2000) Carbon and nitrogen fluxes in sediment inhabited by suspensionfeeding (Nereis diversicolor) and non-suspension-feeding (N. virens) polychaetes. Mar Ecol Prog Ser 192:203-217

Dalsgaard T (ed), Nielsen LP, Brotas V, Viaroli P and 11 others (2000) Protocol handbook for NICE - nitrogen cycling in 
estuaries: a project under the EU research programme: marine science and technology (MAST III). National Environmental Research Institute, Silkeborg

Eilola K, Stigebrandt A (2001) Modelling filamentous algae mats in shallow bays. Report 2001:38. EU life algae LIFE96ENV/S/380

Emmerson MC, Raffaelli DG (2000) Detecting the effects of diversity on measures of ecosystem function: experimental design, null models and empirical observations. Oikos 91: 195-203

Emmerson MC, Solan M, Ames C, Paterson DM, Raffaelli D (2001) Consistent patterns and the idiosyncratic effects of biodiversity in marine ecosystems. Nature 411:73-77

Fauchald K, Jumars PA (1979) The diet of worms: a study of polychaete feeding guilds. Oceanogr Mar Biol Annu Rev 17:193-284

Fleischer S, Hamrin S, Kindt T, Rydberg L, Stibe L (1987) Coastal eutrophication in Sweden: reducing nitrogen in land runoff. Ambio 16:246-251

Fong P, Donohoe RM, Zedler JB (1993a) Competition with macroalgae and benthic cyanobacterial mats limits phytoplankton abundance in experimental microcosms. Mar Ecol Prog Ser 100:97-102

Fong P, Zedler JB, Donohoe RM (1993b) Nitrogen vs. phosphorus limitation of algal biomass in shalllow coastal lagoons. Limnol Oceanogr 38:906-923

Gilbert F, Aller RC, Hulth S (2003) The influence of biogenic irrigation intensity on benthic nitrification and denitrification: an experimental and model approach. Limnol Oceanogr (in press)

Glud RN, Ramsing NB, Gundersen JK, Klimant I (1996) Planar optrodes: a new tool for fine scale measurements of twodimensional $\mathrm{O}_{2}$ distribution in benthic communities. Mar Ecol Prog Ser 140:217-226

Hartog C den (1994) Suffocation of a littoral Zostera bed by Enteropmorpha radiata. Aquat Bot 47:21-28

Havens KE, Hauxwell J, Tyler AC, Thomas S and 5 others (2001) Complex interactions between autotrophs in shallow marine and freshwater ecosystems: implications for community responses to nutrient stress. Environ Pollut 113:95-107

Hodgkin EP, Birch PB (1986) No simple solution: proposing radical management options for a eutrophic estuary. Mar Pollut Bull 17:399-404

Hulth S, Engström P, Selander E, Aller RC (2002) A pH plate fluorosensor for early diagenetic studies of marine sediments. Limnol Oceanogr 47:212-220

Isaksson I, Pihl L (1992) Structural changes in benthic macrovegetation and associated epibenthic faunal communities. Neth J Sea Res 30:131-140

Isaksson I, Pihl L, van Montfrans J (1994) Eutrophicationrelated changes in macrovegetation and foraging of young cod (Gadus morhua L): a mesocosm experiment. J Exp Biol Ecol 177:203-217

Jöborn A, Oscarsson H, Pihl L (1998) A new approach to combat blooms of ephemeral macroalgae in Scandinavian coastal waters. ICES/mini 7

Krause-Jensen D, Christensen PB, Rysgaard S (1999) Oxygen and nutrient dynamics within mats of the filamentous macroalga Chaetomorpha linum. Estuaries 22:31-38

Kristensen E, Blackburn TH (1987) The fate of organic carbon and nitrogen in experimental marine sediment systems: influence of bioturbation and anoxia. J Mar Res 45: 231-257

Li YH, Gregory S (1974) Diffusion of ions in seawater and deep-sea sediments. Geochim Cosmochim Acta 38: $703-714$
Lorenzen CJ (1967) Determination of chlorophyll and pheopigments: spectrophotometric equations. Limnol Oceanogr 12:343-346

Mazik K, Elliott M (2000) The effects of chemical pollution on the bioturbation potential of estuarine intertidal mudflats. Helgol Mar Res 54:99-109

McGlathery KJ, Krause-Jensen D, Rysgaard S, Christensen PB (1997) Patterns of ammonium uptake within dense mats of the filamentous macroalga Chatemorpha linum. Aquat Bot 59:99-115

McGlathery KJ, Anderson IC, Tyler AC (2001) Magnitude and variability of benthic and pelagic metabolism in a temperate coastal lagoon. Mar Ecol Prog Ser 216:1-15

Melin Y (2001) Can marine filamentous algae be used as fertiliser? MSc thesis, Göteborg University

Norkko A, Bonsdorff E (1996) Population responses of coastal zoobenthos to stress induced by drifting algal mats. Mar Ecol Prog Ser 140:141-151

Österling M, Pihl L (2001) Effects of filamentous green algal mats on benthic macrofaunal functional feeding groups. J Exp Mar Biol Ecol 263:15-183

Pelegri SP, Nielsen LP, Blackburn TH (1994) Denitrification in estuarine sediment stimulated by the irrigation activity of the amphipod Corophium volutator. Mar Ecol Prog Ser 105:285-290

Pihl L, Magnusson G, Isaksson I, Wallentinus I (1996) Distribution and growth dynamics of ephemeral macroalgae in shallow bays on the Swedish west coast. J Sea Res 35: 169-180

Pihl L, Svensson A, Moksnes PO, Wennhage H (1999) Distribution of green algal mats throughout shallow soft bottoms of the Swedish archipelago in relation to nutrient loads and wave exposure. J Sea Res 41:281-294

Raffaelli D (2000) Interactions between macro-algal mats and invertebrates in the Ythan estuary, Aberdeenshire, Scotland. Helgol Mar Res 54:71-79

Rysgaard S, Christensen PB, Nielsen LP (1995) Seasonal variation in nitrification and denitrification in estuarine sediment colonized by benthic microalgae and bioturbating infauna. Mar Ecol Prog Ser 126:111-121

Sundbäck K, Miles A (2002) Role of microphytobenthos and denitrification for nutrient turnover in embayments with floating macroalgal mats: a spring situation. Aquat Microb Ecol 30:91-101

Sundbäck K, Jönsson B, Nilsson P, Lindström I (1990) Impact of accumulating drifting macroalgae on a shallow-water sediment system: an experimental study. Mar Ecol Prog Ser 58:261-274

Sundbäck K, Carlson L, Nilsson C, Jönsson B, Wulff A, Odmark S (1996) Response of benthic microbial mats to drifting green algal mats. Aquat Microb Biol 10:195-208

Sundbäck K, Miles A, Göransson E (2000) Nitrogen fluxes, denitrification and the role of microphytobenthos in microtidal shallow-water sediments: an annual study. Mar Ecol Prog Ser 200:59-76

Thornton DCO, Underwood GJC, Nedwell DB (1999) Effect of illumination and emersion period on the exchange of ammonium across the estuarine sediment-water interface. Mar Ecol Prog Ser 28:11-20

Thybo-Christesen M, Rasmussen MB, Blackburn TH (1993) Nutrient fluxes and growth of Cladophora sericea in a shallow Danish bay. Mar Ecol Prog Ser 100:273-281

Trimmer M, Nedwell DB, Sivyer DB, Malcolm SJ (2000) Seasonal organic mineralisation and denitrification in intertidal sediments and their relationship to the abundance of Enteromorpha sp. and Ulva sp. Mar Ecol Prog Ser 203: $67-80$ 
Ullman WJ, Aller RC (1982) Diffusion coefficients in nearshore marine sediments. Limnol Oceanogr 27:552-556

Underwood AJ (1997) Experiments in ecology: their logical design and interpretation using analysis of variance. Cambridge University Press, Cambridge

Valiela I, McClelland J, Hauxwell J, Behr PJ, Hersh D, Foreman K (1997) Macroalgal blooms in shallow estuar-

Editorial responsibility: Otto Kinne (Editor),

Oldendorf/Luhe, Germany ies: controls and ecophysiological and ecosystem consequences. Limnol Oceanogr 42:1105-1118

Viaroli P, Bartoli M, Bondavalli C, Christian RR, Giordani G, Naldi M (1996) Macrophyte communities and their impact on benthic fluxes of oxygen, sulphide and nutrients in shallow eutrophic environments. Hydrobiologia 329: 105-119

Submitted: March 28, 2002; Accepted: September 10, 2002 Proofs received from author(s): December 6, 2002 